\title{
CASE STUDY: THE STATE OF INFORMATION SYSTEMS IN QUEENSLAND UNIVERSITIES
}

\author{
Robert W Smyth \\ School of Information Systems \\ Queensland University of Technology \\ r.smyth@qut.edu.au \\ Guy G Gable \\ School of Information Systems \\ Queensland University of Technology \\ g.gable@qut.edu.au
}

\begin{abstract}
The state of Information Systems (IS) in Queensland reflects the highly decentralised nature of the state. Relative to its population, Queensland has a large number of universities, each of which is engaged in Information Systems teaching and research. The study reveals little evidence of a distinctive Queensland-flavour of Information Systems. Rather, there is a diversity of curriculum approaches and an equally broad range of research foci and approaches to research. Two of the state's regional universities are notable for the relative strength of their IS presence, in terms of number of IS staff, number of IS students and range of campuses across which IS is taught. The breadth of topics and approaches to IS in Queensland is evidenced by the existence of separate, competing IS groups in two of the largest universities; in each case, one of the IS groups is highly technical in orientation while the other is Business oriented. Across the nine Queensland universities there is wide variability in terms of the administrative location of the Information Systems academic staff in the university structure. The study assesses the state of IS in Queensland universities in relation to criteria indicative of the maturity of a discipline. Measured against these criteria, Information Systems in Queensland universities cannot be considered a mature, distinct academic discipline.
\end{abstract}




\section{INTRODUCTION}

For the Information Systems community worldwide, this is a period of great turbulence. There has been over the past three years an unprecedented downturn in demand for Information Technology skills, resulting in a sharp decline in student entry to university IT courses. Information Systems courses have been among those affected by the downturn.

Following the falloff in demand for Information Systems courses has been a major re-examination of Information Systems. Old insecurities about the status of Information Systems as a separate academic discipline have emerged. In universities in Queensland, as elsewhere in the world, Information Systems curricula have been re-analysed with a view to repositioning Information Systems in response to the falloff in student demand. The changes to Information Systems curricula have been accompanied in some instances by administrative restructuring of Information Systems academic staff, driven by the goals of rationalising and economising.

In this setting of introspection and change, there is value in analysing the current state of Information Systems in our universities. From a position of soundly-based understanding of the current status, and some feeling for how this status was arrived at, Information Systems academics are better placed to plan to take advantage of emerging opportunities and to minimise the impact of identified threats to the Information Systems discipline, to Information Systems academics, and to the programs of teaching and research guided by these academics. This study reports on such a study into the state of the Information Systems discipline in universities, in this instance, universities in the state of Queensland.

\section{Purpose of the Queensland Study}

The Queensland study aims to document current characteristics of Information Systems programs and Information Systems research across universities in the state. As with the broader study, this one also seeks: to assess the strength of the IS presence in the state's universities, to evaluate the maturity of IS as an academic discipline, to identify emerging trends in IS, and to identify main influences on IS in the state's universities. These aims are to be seen in the context of debate about what Information Systems is and, significantly, whether IS can legitimately claim to be a distinct academic discipline.

\section{THE RESEARCH METHOD}

The Queensland study utilises the case study method. The specific case study method applied draws heavily on the approach suggested by Yin (2003), incorporating some of the ideas of Walsham (1995). In particular, this version of the case study method seeks an interpretive approach, directed at what Walsham calls “rich insight”. Consistent with Yin's recommendation, the Queensland case study utilises a detailed case study protocol. This protocol was developed by the Queensland study team members with input and consensus from the all Australian study team members. Major objectives of the detailed case study protocol were to facilitate:

- comparability across the States,

- consistency across the individual State case studies, and

- efficiency in the data gathering process. 
The principal data gathering method used in the case study was interviewing. Existing documentary and archival material was also gathered to supplement the interview data and to provide some triangulation of observations. The interviews were semi-structured, of about one hour's duration, with emphasis on broad perceptions by the interviewee on the state of Information Systems in his/her university, points of differentiation, and distinctive features of Information Systems in that university and in other Queensland universities.

\section{THEORETICAL FRAMEWORK GUIDING THE STUDY}

There is a body of knowledge that suggests that many of the characteristics of Information Systems are consistent with those observed across emerging disciplines in the early stages of their development. For example, in the early evolution of Management as a discipline, some of the characteristics that manifested themselves at that time have been seen more recently in the development of Information Systems.

The framework proposed by Ridley (2006) is based on two constructs: (1) degree of professionalisation as a discipline and (2) maturity as a scientific field. Both are derived from Whitley's theory of scientific change (1984a, 1984b).

The first construct concerns the degree of "professionalisation" of the discipline, which is expected to increase as the impact of local contingencies decreases. Where a discipline is not highly professionalised, local contingencies such as political pressures, have high impact. Consequently, the degree of professionalisation of IS can be indicated by the extent of variation in the nature of IS curriculum and research.

The second construct has been derived from Whitley's three conditions for the establishment of a distinct scientific field:

- Scientific reputations both become socially prestigious and "control critical rewards" i.e. those in the discipline have the potential for prestige and power through prominence in that discipline;

- Standards of research competence and skills become established;

- A unique symbol system is developed that allows the exclusion of outsiders and unambiguous communication between initiates within the discipline.

\section{The Universities in this Study}

In this study, data was gathered from all universities in Queensland. There are nine universities in Queensland, of which four have their main campus in Brisbane. All nine universities teach Information Systems on at least one campus. The universities and the campus locations where Information Systems is taught are shown in Table 1.

\begin{tabular}{|l|l|}
\hline University & Campus Locations for IS \\
\hline Australian Catholic University & McAuley College - Brisbane \\
\hline Bond University & Gold Coast \\
\hline Central Queensland University & $\begin{array}{l}\text { Rockhampton; Bundaberg; Gladstone; Mackay; } \\
\text { Emerald; (International Colleges: Melbourne; } \\
\end{array}$ \\
\hline Griffith University & Brisbane; Logan; Gold Coast \\
\hline
\end{tabular}




\begin{tabular}{|l|l|}
\hline James Cook University & Townsville; Cairns; Mackay \\
\hline Queensland University of Technology & Brisbane (2 campuses); Caboolture \\
\hline University of Queensland & Brisbane; Ipswich \\
\hline University of the Sunshine Coast & Sunshine Coast \\
\hline University of Southern Queensland & Toowoomba; Wide Bay \\
\hline
\end{tabular}

Table 1 Campuses of Queensland Universities Where IS Is Taught

\section{Relative Size of the IS Presence in the Queensland Universities}

In total size, three of the Queensland metropolitan universities, University of Queensland, Queensland University of Technology, and Griffith University, rank with the largest universities in Australia. Both University of Queensland and QUT have total student numbers around 40,000, while Griffith student numbers are about 32,000. At the other end of the range, Bond University has about 2,600 students, University of the Sunshine Coast has about 3,200 students, while the Queensland branch of the Australian Catholic University, McAuley College, also has fewer than 5,000 students.

The Information Systems presence at Queensland universities, in terms of the number of IS students, numbers of IS academic staff, and the extent of degree programs and research activities is, not surprisingly, roughly aligned with the size of the universities; larger universities tend to have a stronger IS presence than smaller universities. Some indication of the size of the IS presence in each Queensland university is given in Table 2.

\begin{tabular}{|l|l|l|}
\hline University & $\begin{array}{l}\text { No. of IS } \\
\text { Academics }\end{array}$ & $\begin{array}{l}\text { No. of IS } \\
\text { Students }\end{array}$ \\
\hline Australian Catholic University & $<5$ & $<100$ \\
\hline Bond University & $5-10$ & $<100$ \\
\hline Central Queensland University & $15-20$ & $>1,000$ \\
\hline Griffith University & $>30$ & $>1,000$ \\
\hline James Cook University & $<5$ & $<100$ \\
\hline Queensland University of Technology & $>30$ & $>1,000$ \\
\hline University of Queensland & $20-25$ & $>1,000$ \\
\hline University of the Sunshine Coast & $5-10$ & $100-200$ \\
\hline University of Southern Queensland & $25-30$ & $>1,000$ \\
\hline
\end{tabular}

Table 2 The Size of the IS Presence in Qld Universities

Table 2 shows, for each of the universities, a range to indicate the number of staff and to indicate the number of IS students. The objective is to provide some relativities in relation to the size of the IS presence across the state's universities. The use of broad ranges also serves to overcome inconsistencies in terms of what respondents deem to be "IS Academics" and "IS Students". In some instances, an IS academic may also teach subjects in related disciplines; sessional staff may or may not be reported in Full Time Equivalents. Similarly, IS students may be seen by some to include only those students who are studying an IS major, or equivalent, while others will include all students studying even the equivalent of a minor in IS. The number of IS academics at a university is perhaps the better guide to the size of the IS presence. 
In general, it can be said that Information Systems has a strong presence in Queensland universities. While the larger universities tend to have the larger IS presence, two of the regional universities, which are far smaller than the three large Brisbane-based universities, stand out for the relative size of their Information Systems groups. These two are University of Southern Queensland (USQ) and Central Queensland University (CQU). At USQ, the Department of Information Systems is by far the largest of 7 departments within the Faculty of Business, with almost 25\% of the Faculty's enrolment. Another indicator of the relative size of Information Systems at USQ is that "the Department of Information Systems has more students than the whole Faculty of Engineering”. While the relative size of Information Systems at CQU is not quite as great as at USQ, it is still disproportionately large in terms of student numbers, staff numbers, and range of programs/courses offered, compared with the overall size of the university.

The common feature at USQ and CQU, largely absent in the other Queensland universities, is a very strong external-studies offering in Information Systems. In fact, about 70\% of USQ Information Systems students are external students. Both USQ and CQU have long pursued a strategy of placing heavy emphasis on external studies. The consequence of heavy external enrolments, allied to a policy of setting up study centres in the Australian east-coast capital cities, means that only very small proportions of their Information Systems students attend at the home campuses of Toowoomba and Rockhampton respectively. The strength of external studies in Information Systems at these two regional universities can be seen as a distinctive feature of the state of Information Systems in universities in Queensland.

\section{The Administrative Placement of IS in Queensland Universities}

Across the nine Queensland universities there is remarkable variability in terms of the administrative location of the Information Systems academic staff in the university structure. Table 3 shows, firstly, the administrative entity with which the Information Systems academics at that university are affiliated. It should be noted at this point that it is common to find academics involved with aspects of Information Systems across a range of Departments, Schools and Faculties in a given university; for instance, some Health Informatics in a health faculty, Information Systems Auditing in a School of Accounting, and so on. In this study, data was collected in connection with only the groups who self-identify as teaching and/or researching Information Systems in each university.

A feature of Information Systems in Queensland universities is that during the period late-2004 to mid-2005, many of the Information Systems groups had either just participated in restructuring or were about to commence a restructuring process. CQU, Griffith, James Cook, and USQ Information Systems academics were about to be involved in a review process. Bond University Information Systems staff were involved in restructuring in June 2005 and QUT Information Systems academics were in the process of a restructuring. The downturn in demand for IT courses was cited as a major stimulus for restructuring.

It can be seen from Table 3 that five of the nine Queensland universities have Information Systems academics in a separate School or Department. Interestingly, no two of these five use exactly the same terminology to describe their Information Systems administrative entity. The remaining four universities, Bond University, James Cook University, University of Queensland, and University of Sunshine Coast, have IS academic staff placed in administrative entities within other Departments, Schools or Faculties. In these four instances, the administrative entities are identified as discipline groups. 


\begin{tabular}{|c|c|c|}
\hline University & Administrative Entity & Home Faculty \\
\hline $\begin{array}{l}\text { Australian } \\
\text { Catholic } \\
\text { University }\end{array}$ & School of Business and Informatics & Arts and Sciences \\
\hline Bond University & $\begin{array}{l}\text { Informal IS Group within School of } \\
\text { Information Technology }\end{array}$ & Business \\
\hline $\begin{array}{l}\text { Central } \\
\text { Queensland } \\
\text { University }\end{array}$ & School of Information Systems & $\begin{array}{ll}\text { Informatics } & \text { and } \\
\text { Communications } & \end{array}$ \\
\hline $\begin{array}{l}\text { Griffith } \\
\text { University }\end{array}$ & $\begin{array}{l}\text { School of Information Communications } \\
\text { and Technology/Informal IS Group in } \\
\text { School of Management }\end{array}$ & $\begin{array}{l}\text { Engineering and Information } \\
\text { Technology/Business and } \\
\text { Law }\end{array}$ \\
\hline $\begin{array}{ll}\text { James } & \text { Cook } \\
\text { University } & \\
\end{array}$ & Informal IS Group in School of Business & $\begin{array}{l}\text { Law, Business and Creative } \\
\text { Arts }\end{array}$ \\
\hline $\begin{array}{l}\text { Queensland } \\
\text { University of } \\
\text { Technology }\end{array}$ & School of Information Systems & Information Technology \\
\hline $\begin{array}{l}\text { University of } \\
\text { Queensland }\end{array}$ & $\begin{array}{l}\text { Information Systems Cluster in Business } \\
\text { School; } \\
\text { Data and Knowledge Engineering } \\
\text { Division in School of Information } \\
\text { Technology and Electrical Engineering }\end{array}$ & $\begin{array}{l}\text { Business, Economics and } \\
\text { Law/ } \\
\text { Engineering, Physical } \\
\text { Sciences \& Architecture }\end{array}$ \\
\hline $\begin{array}{l}\text { University of the } \\
\text { Sunshine Coast }\end{array}$ & $\begin{array}{l}\text { Information Systems Discipline Group } \\
\text { in Faculty of Business }\end{array}$ & Business \\
\hline $\begin{array}{l}\text { University of } \\
\text { Southern } \\
\text { Queensland }\end{array}$ & Department of Information Systems & Business \\
\hline
\end{tabular}

Table 3 Administrative Placement of the IS Group in Qld Universities, June 2005

In turn, the "home” Faculty for each Information Systems group also shows some variability across the nine Queensland universities. At JCU, Bond, USC and USQ, the home or parent Faculty for the IS academics is Business (or some variant on that title). At QUT the home Faculty for IS academics is a Faculty of Information Technology. Both Griffith University and University of Queensland are distinctive in two respects in relation to the administrative placement of their Information Systems academics: Firstly, both Griffith University and University of Queensland are characterised by two separate Information Systems groups. At Griffith, the smaller of the two groups is within the School of Management in the Faculty of Business and Law. The second, and larger, Information Systems group at Griffith University is distinctive in being administratively alongside Engineering, in a Faculty of Engineering and Information Technology. At University of Queensland, the larger of the two Information Systems groups is in the Business School, while the second IS group, somewhat akin to Griffith, is within a School of Information Technology and Electrical Engineering. The placement of the IS group at the Australian Catholic University within a Faculty of Arts and Science appears anomalous until it is observed that ACU has only three faculties, the other two being Health and Education. 
In terms of independent status for Information Systems groups in Queensland universities, there is evidence of two contradictory trends. On the one hand, at such universities as CQU, Griffith and QUT, Information Systems academics have moved into separate, identifiable Schools of Information Systems. On the other hand, at USQ a separate School of Information Technology, formed in 1990 to include both Information Systems and Computer Science, was broken up in 1993, with Information Systems returning to the Business Faculty. Similarly, the Faculty of Information Technology at Bond University, which incorporated the Information Systems group (and Computer Science) was disbanded in June 2005, with all Information Technology being absorbed, as a new School of Information Technology, within the Faculty of Business. So, while some Information Systems groups have been moving out of Business faculties in Queensland, others have been moving back into Business.

Sherer (2002) asserts that both the theoretical basis of the discipline and the curricular needs of the professional community influence the organisational placement of the Information Systems group. The assertion seems most plausible. If we assume that: 1 . theoretical basis of the discipline, and 2. perceived curricular needs of the local community, are two significant determinants of the administrative placement of IS groups, it is possible to make inferences about these factors from the differing placements in universities across the state. These inferences can provide useful insights regarding the maturity of Information Systems as a distinct academic discipline. This matter of maturity of the discipline is analysed in a later section of the report.

\section{Distinctive Features of Information Systems Curriculum}

The Queensland universities offer a wide range of both undergraduate and postgraduate Information Systems courses/programs. Table 4 summarises the main Information Systems courses currently presented in the Queensland Universities. It is clear from the table that there is much variety in Information Systems courses across the state. At the coarsest level of analysis, it can be seen that the Information Systems courses bear a wide range of nomenclatures. Within these obvious differences in degree names, in the Queensland universities there is considerable further variability in Information Systems curriculum content. One obvious area of variability in curriculum content relates to the amount of "technical” emphasis in different courses. At QUT and Bond University, for instance, at least twenty of the twenty-four units in the undergraduate Information Systems degree course are from the Faculty of Information Technology. The Information Systems units offered within the School of Information Technology and Electrical Engineering at University of Queensland are characterised by the fact that every one of them has a technical focus. By contrast, the Information Systems undergraduate degrees in the universities where the IS group is located within a Business Faculty tend to include a number (typically 4-6) of compulsory Business units. The same variability in IS curriculum content is to be observed in the coursework postgraduate Information Systems courses across the Queensland universities.

\begin{tabular}{|l|l|l|}
\hline University & $\begin{array}{l}\text { Undergraduate } \\
\text { Courses/Programs }\end{array}$ & $\begin{array}{l}\text { Postgraduate } \\
\text { Courses/Programs }\end{array}$ \\
\hline Australian Catholic University & BIS & MIS \\
\hline Bond University & BIS (discontinued after & GradDipIT \\
& School's move to Faculty of & MIT(Prof) \\
& Business) & MIT(Exec) \\
& BIT(IS) & MIT(Hons) \\
& & MITM \\
\hline
\end{tabular}




\begin{tabular}{|c|c|c|}
\hline Central Queensland University & $\begin{array}{l}\text { BBus(IS) } \\
\text { BEC } \\
\text { BIT (Bio-informatics) }\end{array}$ & $\begin{array}{l}\text { GradCertIS } \\
\text { GradDipISManagement } \\
\text { MIS } \\
\text { GradCert } \\
\text { Informatics } \\
\text { GradDip } \\
\text { Informatics } \\
\text { Master of Health } \\
\text { Informatics } \\
\text { PhD }\end{array}$ \\
\hline Griffith University & $\begin{array}{l}\text { BIT } \\
\text { BBus(Commercial Comp) }\end{array}$ & $\begin{array}{l}\text { MIT } \\
\text { MIT(Advanced) } \\
\text { MeCom } \\
\text { MIS } \\
\text { MIS (Advanced) } \\
\text { MSoftEng } \\
\text { MStrategicInfSysMgt } \\
\text { PhD }\end{array}$ \\
\hline James Cook University & BCom & $\begin{array}{l}\text { MCom } \\
\text { MBA-MInfTech } \\
\text { PhD }\end{array}$ \\
\hline $\begin{array}{lll}\text { Queensland } & \text { University of } \\
\text { Technology } & \end{array}$ & BInfTech(IS) & $\begin{array}{l}\text { BInfTech(Hons) } \\
\text { GradDipInfTech } \\
\text { MInfTech } \\
\text { MInfTech(Advanced) } \\
\text { PhD }\end{array}$ \\
\hline University of Queensland & $\begin{array}{l}\text { BCom } \\
\text { BeCom } \\
\text { BBusMan } \\
\text { BInfTech }\end{array}$ & $\begin{array}{l}\text { MCom(IS) } \\
\text { MCom(eCom) } \\
\text { MSc(Comp Sc) } \\
\text { MEng } \\
\text { MInfTech } \\
\text { PhD } \\
\end{array}$ \\
\hline University of the Sunshine Coast & $\begin{array}{l}\text { BBus(IS) } \\
\text { BICT }\end{array}$ & $\begin{array}{l}\text { GradDipIS } \\
\text { MInfTech(Research) } \\
\text { PhD } \\
\end{array}$ \\
\hline $\begin{array}{lll}\text { University of } & \text { Southern } \\
\text { Queensland } & & \end{array}$ & $\begin{array}{l}\text { BBus } \\
\text { BIT }\end{array}$ & $\begin{array}{l}\text { GradDipInfTech } \\
\text { GradDipInfSys } \\
\text { MInfSys } \\
\text { MIT(Research) } \\
\text { MIT(Prof) } \\
\text { PhD }\end{array}$ \\
\hline
\end{tabular}

Table 4 Information Systems Courses in Queensland Universities

Another aspect of variability of Information Systems curricula across Queensland universities is in the demarcation between Information Systems and related discipline areas in relation to which discipline area has curriculum responsibility for specific topic areas. For instance, at CQU no programming subjects are controlled by Information Systems staff, being, instead, the domain of Computer Science staff. Yet CQU has strong representation in its course curricula from such topic areas as Management Support Systems and Health Informatics, topic areas covered by other 
Faculties in some other Queensland universities. Topic areas such as database and data communications, as well as a range of web-related topics, are other examples of curriculum areas that lie within the ambit of the Information Systems academic departments at some Queensland universities and, yet, with other departments at other universities.

\section{Distinctive Features of Information Systems Research}

As with Information Systems curriculum, diversity is a feature of Information Systems research in Queensland universities. Table 5 summarises major foci for Information Systems research in Queensland universities and the organisational approaches to promote research. Again, the diversity of topics highlights the breadth that appears to characterise Information Systems. Once again also, the research foci of the individual universities do not appear to be closely related to geographical factors local to each university. Instead, the research areas appear to reflect the specific interests and skills of the academic research leaders. Again, there is evidence from some of the Queensland universities of a policy to deliberately focus on global Information Systems issues in preference to purely local ones.

Nor is there any consistent pattern in the organisational approaches of the universities in seeking to promote and support Information Systems research in Queensland universities. While some universities have established formal groups and programs and Research Centres, others, like the two Information Systems groups at University of Queensland, which has a long tradition of research, rely on voluntary collaborations. Some of the groupings have a tight Information Systems focus, while others, like James Cook University, foster broad cross-discipline collaborations.

\begin{tabular}{|c|c|c|}
\hline University & Areas of IS Research Focus & IS Research Groupings \\
\hline $\begin{array}{ll}\text { Australian } & \text { Catholic } \\
\text { University } & \end{array}$ & $\begin{array}{l}\text { Business requirements definition; } \\
\text { Software quality assurance; } \\
\text { Management of information systems; } \\
\text { Systems modelling and simulation }\end{array}$ & Individual \\
\hline Bond University & $\begin{array}{l}\text { Smart supply chain; } \\
\text { Business intelligence }\end{array}$ & Smart Enterprise Centre \\
\hline $\begin{array}{l}\text { Central Queensland } \\
\text { University }\end{array}$ & $\begin{array}{l}\text { Health Informatics; } \\
\text { Group solutions (GDSS); } \\
\text { Teaching and Learning; } \\
\text { Multimedia }\end{array}$ & $\begin{array}{l}\text { No Research Centres; } \\
\text { Research Clusters from } \\
\text { across Schools in the } \\
\text { Faculty }\end{array}$ \\
\hline Griffith University & $\begin{array}{l}\text { Software Quality; } \\
\text { Packaged software; } \\
\text { Decision support systems; } \\
\text { Programming methodology; } \\
\text { Gender and IT; } \\
\text { Information Systems Analysis, Design, } \\
\text { Development and Implementation; } \\
\text { Information Systems Security; } \\
\text { Information Systems Strategy; } \\
\text { End User Issues; } \\
\text { Knowledge Management; } \\
\text { Rural Information Systems }\end{array}$ & $\begin{array}{l}\text { Software } \\
\text { Institute; } \\
\text { Institute for Integrated } \\
\text { and Intelligent Systems; } \\
\text { IS Group in Department } \\
\text { of Management }\end{array}$ \\
\hline $\begin{array}{ll}\text { James } & \text { Cook } \\
\text { University } & \end{array}$ & $\begin{array}{l}\text { People, identity and place: intellectual, } \\
\text { social, economic and cultural dynamics; } \\
\text { gender and IT }\end{array}$ & $\begin{array}{l}\text { Collaborative; } \\
\text { Faculty }\end{array}$ \\
\hline
\end{tabular}




\begin{tabular}{|c|c|c|}
\hline $\begin{array}{l}\text { Queensland } \\
\text { University } \\
\text { Technology }\end{array}$ & $\begin{array}{l}\text { IT Professional Services: } \\
\text { Knowledge Management; } \\
\text { Enterprise Systems Success Factors; } \\
\text { Information Technology Sourcing ; } \\
\text { The Management Consulting Process ; } \\
\text { Information Management in Business } \\
\text { Processes; } \\
\text { ERP Life Cycle Knowledge Management; } \\
\text { Business Process Management; } \\
\text { Workflow Patterns; } \\
\text { Workflow tools; } \\
\text { Web service design \& implementation }\end{array}$ & $\begin{array}{l}\text { Centre for Information } \\
\text { Technology Innovation: } \\
\text { IT Professional Services } \\
\text { (ITPS) Research Program; } \\
\text { Business r Process } \\
\text { Management } \\
\text { Research Program }\end{array}$ \\
\hline $\begin{array}{l}\text { University } \\
\text { Queensland }\end{array}$ & $\begin{array}{l}\text { Data Quality; } \\
\text { E-Commerce; } \\
\text { IT Governance; } \\
\text { Mobile Communications } \quad \text { (Security } \\
\text { Aspects); } \\
\text { Knowledge Management; } \\
\text { Computer Forensics; } \\
\text { Ontological Analysis; } \\
\text { Enterprise Computing (workflows,...); } \\
\text { Spatial Databases }\end{array}$ & $\begin{array}{ll}\text { Voluntary } & \text { collaborative } \\
\text { groupings } & \end{array}$ \\
\hline $\begin{array}{l}\text { University of the } \\
\text { Sunshine Coast }\end{array}$ & $\begin{array}{l}\text { Knowledge Management; } \\
\text { Data mining }\end{array}$ & $\begin{array}{l}\text { Faculty Research Centre, } \\
\text { SCRIBE }\end{array}$ \\
\hline $\begin{array}{l}\text { University of } \\
\text { Southern Queensland }\end{array}$ & $\begin{array}{l}\text { Eclectic: } \\
\text { e-Business; } \\
\text { IS education; } \\
\text { Knowledge Management; } \\
\text { IS development methodologies }\end{array}$ & $\begin{array}{l}\text { eBARC }- \text { Electronic } \\
\text { Business Advisory \& } \\
\text { Research Centre, Faculty- } \\
\text { wide }\end{array}$ \\
\hline
\end{tabular}

Table 5 IS Research Foci and Groupings for IS Research in Queensland Universities

\section{Key Figures Who Have Influenced IS in Queensland Universities}

Senior academics in Information Systems in Queensland universities cite a wide range of individuals as having been significant to the development of Information Systems teaching and research in their universities. In most instances, prominent Information Systems academics in the early days of Information Systems at the university in question were viewed as having had the greatest impact e.g. Ed Fitzgerald at USQ. Less commonly, outside figures were cited. At Bond University, British academic Frank Land, an early advisor to Bond, was proposed as a most influential individual. At QUT, it was John Puttick, a prominent IT proprietor and practitioner, and Chair of the Faculty Advisory Committee. At USC, Ron Weber and Guy Gable were nominated as significant influences because of their prominence internationally as Information Systems researchers, and Alan Underwood, another Queensland IS academic, who had made a significant contribution to the Australian Computer Society.

\section{The Status of IS as a Distinct Discipline in Queensland Universities}

To analyse the status of Information Systems as a distinct discipline, we turn initially to the two constructs from Whitley (1984a; 1984b) outlined earlier in this report viz. Professionalisation, and 
Conditions for Acceptance as a Scientific Field. Where a discipline is not highly professionalised, Whitley argues that local contingencies have high impact. From the data collected in Queensland universities, there is little evidence of Information Systems curriculum or research effort being focused on accommodating local community characteristics. Nonetheless, as has been pointed out in an earlier section of this report, within the Queensland universities there is considerable variability in curriculum content. It can be argued that this variability in Information Systems content is primarily attributable to a specific local contingency factor. That factor is the Information Systems leadership in each university. Even within a single university, sharp changes in curriculum content can be seen where leadership of the Information Systems group changes. An example of this is University of the Sunshine Coast, where the curriculum moved abruptly from a focus on Soft Systems approaches to a much more "technical" curriculum following a change in the Information Systems leader at that University.

As observed in the earlier discussion on the Information Systems curriculum in each of the Queensland universities, there is a lack of consistency across the universities with regard to subject areas that properly "belong” to Information Systems staff as opposed to staff from Computer Science, Multi Media, Business, or some other academic group. This observation of the absence in Queensland universities of a "core body of knowledge" defining Information Systems, is consistent with the wider observations of Fitzgerald (2003). Fitzgerald concludes that the absence of such a core body of knowledge relegates Information Systems to "a subject with a particular perspective" rather than a discipline. Certainly, this lack of clear boundaries on what constitutes Information Systems counts against acceptance of Information Systems as a mature, distinct academic discipline.

\section{REVIEW OF FINDINGS}

While the study points to a considerable diversity in Information Systems across the nine universities in Queensland, there was little evidence of sharply different "philosophies" of Information Systems as was reported from a survey of Information Systems in eighteen European countries (Avgerou et al, 1999). The European study had, for instance, highlighted the strong sociotechnical stance of the Scandinavian countries, in contrast to a pragmatic technical emphasis in German universities. In the curricula and research emphases of the Queensland universities there was evidence of an eclectic melding of the various European and American approaches. Only at University of Queensland and at Griffith University, both of which maintain two strong Information Systems groups, one "technical" and the other "Business-focused", is this blending of approaches to Information Systems not in place in a single administrative unit.

In relating the Queensland data to Whitley's (1984b) three criteria for the establishment of a distinct scientific discipline, it has to be said that the evidence from Queensland universities does not fully support Information Systems being recognised as a distinct discipline. Whitley's first criterion, that those in the discipline have the potential for prestige and power through prominence in that discipline would appear to be met. At several of the Queensland universities, senior Information Systems academics are recognised by their universities as Professor of Information Systems. These individuals are recognised, by virtue of their achievements in Information Systems, as warranting the same prestige and decision-making power in the university as their colleagues in longestablished disciplines. In relation to the second criterion, that standards of research competence and skills become established, there is ongoing debate within the Information Systems community itself, world-wide. Some would argue that the lack of a sound body of accepted Information Systems theory is evidence that these "standards of research competence" have not been met. Again, in 
relation to Whitley's third criterion, that a unique symbol system is developed that allows the exclusion of outsiders and unambiguous communication between initiates within the discipline, there is limited evidence from the Queensland data to suggest that Information Systems academics in Queensland share such a common unique symbol system. The wide variability in curriculum content and research foci would, alone, argue against this unique basis for communication among the Information Systems academics.

In summary, the features of the Information Systems activities observed in Queensland universities have much in common with features reported by Whitley (1984a) in relation to the early stages of the development of Management as a discipline area viz.:

- A heavy reliance on reference disciplines

- A paucity of theory specific to the discipline

- A perceived lower status than for established disciplines, leading to the adoption of methods from the higher status disciplines

- Limited numbers of textbooks that review the discipline

- Poor definition of the boundaries of study

- Incorporation organisationally as a sub-set of an established discipline.

Whitley uses the term "fragmented adhocracy" to describe this immature stage of the development towards a distinct discipline.

\section{LIMITATIONS, AND FUTURE RESEARCH}

The Queensland study draws only patchily on historical data related to the development over time of Information Systems in the nine Queensland universities. In some universities there was historical data readily available, while in others there was not. Where historical data was available to the researchers, there was a richer context for analysis to understand the current situation. The value to the researchers of such limited historical data as was available, points to improved insights from an extension of this study, incorporating a fuller historical analysis.

A feature highlighted in the execution of this study was the dynamic state of Information Systems in Queensland universities at the time of the study. Hence, the study represents a snapshot of a rapidly changing scene. To capitalise on the findings of this study, there is an imperative to replicate it over time. A longitudinal view of the state of Information systems in Queensland universities will tell much about the maturing of Information Systems as a discipline.

\section{General Learnings from the Queensland Study}

In conducting this Queensland study, there was recognition by the researchers of the intention to reflect on the procedures followed and the outcomes achieved; this and the other Australian studies were to inform subsequent, broader studies into the state of Information Systems. A similar study into the state of Information Systems in universities in the countries of the Pacific-Asia region had been planned to follow the Australian study, as mentioned earlier in this paper.

A useful learning from the Queensland study relates to the approach to data gathering that had been proposed in the study protocol. The intention had been to have interviews with at least one key person from each university in the state as the prime source of data. These interviews were planned to take about one hour each. In the event, arranging face-to-face interviews at two of the 
Queensland universities proved impractical. For both James Cook University and the Australian Catholic University telephone interviews were used, followed up by interview notes and other exchanges by e-mail between the researcher and the interviewees.

For future studies elsewhere, a revised study protocol has been prepared to accommodate telephone interviews. In addition, out of recognition of the large time requirements for interviewing where there are many universities involved in the study, a survey instrument has been prepared as a substitute for each interview. The instrument attempts to provide some of the richness of an interview by minimising questions seeking specific numerical responses, in favour of questions teasing out the distinctive characteristics of the university. In recognition of a study environment where, on the other hand, there are very few universities in the study, a guideline for conducting focus groups, based on the standard data gathering framework, has been added to the study protocol.

The use of a theory framework to guide the data gathering and analysis, based on "the emergence of a discipline”, proved most helpful to the conduct of the Queensland study. In fact, the framework adopted for the Queensland study was based on an early version of the framework outlined by Ridley earlier in this volume. Progressive refinement of this framework, in light of the experiences in the Queensland study, and other state studies, will prove valuable to similar future studies.

\section{REFERENCES}

Avgerou C., Siemer J., \& Bjørn-Andersen N. (1999) “The academic field of information systems in Europe”, European Journal of Information Systems, Vol 8 No 2, pp 136-153.

Fitzgerald, G. (2003) “Information Systems: A subject with a particular perspective, no more, no less”, European Journal of Information Systems, Vol 12 No 3, pp 225-228.

Ridley, G. (2006) “Characterising Information Systems in Australia: A Theoretical Framework”, Australasian Journal of Information Systems, Vol 13 No 3, pp. 38-60.

Sherer, S.A. (2002) “Academic Departments of Information Systems Faculty in the U.S.”, Journal of Information Systems Education, Vol 13 No 2, pp 105-116.

Walsham, G. (1995) “Interpretive Case Studies in IS Research: Nature and Method”, European Journal of Information Systems, No 4, pp 74-81.

Whitley, R. (1984a) “The Development of Management Studies as a Fragmented Adhocracy”, Social Science Information, Vol 23 Nos 4/5, pp 775-818.

Whitley, R. (1984b) The Intellectual and Social Organization of the Sciences, Clarendon Press, Oxford, UK.

Yin, R.K. (2003) Case study research: design and methods, $3^{\text {rd }}$ ed., Sage Publications, Thousand Oaks. 


\section{THE AUTHORS}

Dr Bob Smyth is a Research Associate within the IT Professional Services Research Program at Queensland University of Technology. He holds an MSc from Aston University and a $\mathrm{PhD}$ from Queensland University of Technology. His main research interests include IT Professional Services, Computer Aided Software Engineering and Enterprise Systems. He has a particular interest in the Case Study method. In recent years he has been heavily involved in the guidance of $\mathrm{PhD}$ candidates in Information Systems.

Professor Guy G. Gable Chairs the IT Professional Services Research Program, Faculty of Information Technology, Queensland University of Technology http://sky.fit.qut.edu.au/ gable/. His $\mathrm{PhD}$ is from University of Bradford and MBA from Ivey Business School. He is Senior Editor Journal of Strategic Information Systems, Associate Editor MISQ, and on the Editorial Boards of Journal of the AIS, Information Systems Frontiers, and Australasian Journal of Information Systems. Key research interests include IT Professional Services, IT Research Methods, Enterprise Systems, and IT Evaluation. Career emphasis is on research Collaboration with industry and the professions - Chief Investigator $(\$ 2.0 \mathrm{M}+)$ on grants with Accenture, SAP, Institute of Management Consultants, and Queensland Treasury. He has published $>100$ refereed journal articles, conference papers and books.
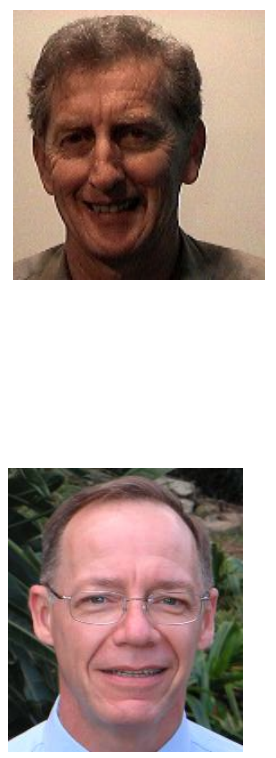